\title{
ADJUSTING THE TRAINING PROCESS IN JUDO ACCORDING TO PHYSICAL AND FUNCTIONAL PARAMETERS
}

Giorgi Zubitashvili

Ilia State University, Tbilisi, Georgia

\begin{abstract}
Research background and hypothesis. The specificity of the technical performance in judo demands from athletes to perform fast and powerful actions at a high level, therefore, much importance is given to the development of aerobic capacity and supporting motor system, in particular, strength of the hand-grip function.

Research aim was to study the judoka's hand-grip strength and lung vital capacity indices in the aspect of age and weight categories and find out the relation between those two factors as well as the most characteristic age period of motor development.

Research methods. The studies were carried out in the preparatory periods of 2009-2011 training cycles. The subjects were 2000 male judokas in 8 different weight categories. The measurements were made using a dynamometer and dry spirometer. The obtained results were statistically processed by SPSS 19, using ANOVA test.

Research results. Research results showed that the judoka's hand-grip and lung vital capacity average indices increased in each higher age and weight category, but this increase was not regular. The most obvious period of motor development at which increase in results was most noticeable was 13-15 years of age. The increase in the hand-grip strength and lung vital capacity in the age and weight categories were inversely proportional, and we found a correlation between them.

Discussion and conclusion. We suggest that there is a close relationship between motor system and the muscles participating in respiration.
\end{abstract}

Keywords: hand grip, lung vital capacity, data dynamics, practical use.

\section{INTRODUCTION}

$\mathrm{T}$ Training judo athletes' motor skills and developing anthropometric qualities is different from those of untrained persons and representatives of other kinds of sports (Marchocka, 1992; Jagiełlo, Kalina, 2007). These differences are mainly caused by the specific nature of training and skills developed in training sessions and due to the morphological changes in their bodies.
The judoka develops certain specific motor characteristics/skills at the very initial stage of training-learning process when the body is influenced by various exercises intended for general and special development (Zubitashvili, 2010).

In the judoka training process the greatest attention is paid to the development of fast and powerful motor skills, which implies synchronic 
development of strength and respiratory capacities. According to D. Chitashvili et al. (2010) from bio motor abilities, the development of hand grip strength is the priority; and aerobic capacity indicators are the increase in lung vital capacity.

Hand muscles, hand grip muscles in particular, participate in all manipulative activities realized by the cranial part of the body; thus they have a significant role in habitual, ordinary or specific professional work as well as in sport activities or in sport testing, talent selection or prognostic criteria. According to M. Dopsaj et al. (2007) and D. Leyk et al. (2007), hand grip strength is not always the same, along with gender and age it also depends on the specificity of the type of sports.

According of I. Banovic (2001), it is well known that persons under the experiment with more strength in hand muscles are more successful in wrestling because having strong hands they can block the opponent's offensive actions, control the space between themselves and the rival and manage to take more favorable positions for the realization of their own attack.

In judo, besides hand grip strength much attention is paid to the rational use of it in practice, in particular the correct hand-grip in order to take a favorable fighting position. According to J. Pedro (2001), judo is impossible without using stances and grips correctly. In addition, during all time of wrestling judoka has to fight continuously for taking the advantageous position for hand-grip.

It has been stated that the development of hand grip strength and aerobic capacity do not differ between elite and non-elite judokas (Franchini et al., 2005), but it is also obvious that their values are directly related to the quality of body working ability, being one of the most important conditions for success (Chitashvili, 2005). Despite the above described studies providing useful information, we still do not come across such complex problem resolution approaches which would be able to establish judokas' physical abilities and functional capacities (in our case, hand-grip strength and lung vital capacity) in the aspect of age and weight categories. This fact determined our goal.

Research aim was to study judoka's handgrip strength and lung vital capacity indices in the aspect of age and weight categories and find out the relations between these two factors as well as the most characteristic age period of motor development.

The tasks of the research. Aiming at achieving this goal we have to solve the following tasks:
1. Establish the average indices of hand grip strength and lung vital, capacity compare them by age and weight categories and determine the age when the greatest results are observed.

2. Determine of possible correlations between the data.

\section{RESEARCH METHODS}

The subjects. The research was conducted during three identical preparation periods (20092011) of the training cycle for male judokas aged 8-20 years, training at 10 different sports schools of Georgia.

Experiment included the 2000 judokas from the total number of persons (2314) who were selected at random. They were in 8 different weight categories (20-30, 31-40, 41-50, 51-60, 61-70, 71-80, 81-90 and $91-100 \mathrm{~kg}$ ). The sum of weight categories at all ages made 50. Each of them consisted of 40 judokas.

Distribution of judokas in the experiment by age and weight categories is provided in Table 1.

Measures. The hand-grip strength was measured in the dominating hand using the $90 \mathrm{~kg}$ scale dynamometer (\# 13968). The persons under the experiment were given a task to squeeze the dynamometer with maximum capacity and show the maximal ability of hand grip.

Lung vital capacity was determined by dry spirometer (TУ 64-1-2267-77). The persons under the experiment were given a task to exhale into the spirometer with their maximum capacity after taking a deep breath. The data from the persons under the experiment were obtained after finishing the first part of the exercise in standing position. Three attempts for each device were allowed, the best result was recorded.

The aforementioned research methods made it possible to study the indices of the judokas' handgrip strength and the lung vital capacity by age and weight categories perfectly and to create the necessary numeral standards for identification of their athletic ability.

Statistics. Statistical analysis of the data was carried out by using the software package SPSS 19 for Windows. The ANOVA test was used to determine the effect of age $(8,9,10,11,12,13,14$, $15,16,17,18,19$ and 20 years) and weight (20$30 ; 31-40 ; 41-50 ; 51-60 ; 61-70 ; 71-80 ; 81-90$ and $91-100 \mathrm{~kg}$ ) on hand grip strength and lung vital capacity. Descriptive data were presented as means, SD, Standard Error, Max and Min. The 
Note: The Judokas were involved in the learningtraining process by the program approved by the National Federation of Judo of Georgia in 2008, in accordance with the admitted worldwide KIU program which serves harmonious development and professional formation to judokas (Hence, certainty can be said that the training by aforementioned program in comparison with development of other characteristics does not cause any special increase in either the strength of hand-grip or lung vital capacity).

\begin{tabular}{|c|c|c|c|c|c|c|c|c|c|c|}
\hline \multicolumn{2}{|c|}{ Count } & \multicolumn{8}{|c|}{ Weight categories } & \multirow[t]{2}{*}{ Total } \\
\hline & & $\begin{array}{l}e \\
\grave{n} \\
\text { गे }\end{array}$ & $\frac{P}{9}$ & $\frac{p}{p}$ & $\begin{array}{l}8 \\
\frac{1}{10}\end{array}$ & $\frac{R}{\frac{1}{6}}$ & $\frac{\infty}{1}$ & $\frac{a}{\infty}$ & $\frac{8}{\frac{1}{a}}$ & \\
\hline \multirow[t]{13}{*}{ Age } & 8 & 40 & 40 & 40 & 0 & 0 & 0 & 0 & 0 & 120 \\
\hline & 9 & 40 & 40 & 40 & 0 & 0 & 0 & 0 & 0 & 120 \\
\hline & 10 & 40 & 40 & 40 & 0 & 0 & 0 & 0 & 0 & 120 \\
\hline & 11 & 0 & 40 & 40 & 40 & 0 & 0 & 0 & 0 & 120 \\
\hline & 12 & 0 & 40 & 40 & 40 & 0 & 0 & 0 & 0 & 120 \\
\hline & 13 & 0 & 40 & 40 & 40 & 40 & 0 & 0 & 0 & 160 \\
\hline & 14 & 0 & 0 & 40 & 40 & 40 & 40 & 0 & 0 & 160 \\
\hline & 15 & 0 & 0 & 0 & 40 & 40 & 40 & 40 & 0 & 160 \\
\hline & 16 & 0 & 0 & 0 & 40 & 40 & 40 & 40 & 40 & 200 \\
\hline & 17 & 0 & 0 & 0 & 40 & 40 & 40 & 40 & 40 & 200 \\
\hline & 18 & 0 & 0 & 0 & 40 & 40 & 40 & 40 & 40 & 200 \\
\hline & 19 & 0 & 0 & 0 & 0 & 40 & 40 & 40 & 40 & 160 \\
\hline & 20 & 0 & 0 & 0 & 0 & 40 & 40 & 40 & 40 & 160 \\
\hline \multicolumn{2}{|c|}{ Total } & 120 & 240 & 280 & 320 & 320 & 280 & 240 & 200 & 2000 \\
\hline
\end{tabular}

level of significance was set at $\mathrm{p}<0.05$ (For detail sample size distribution see Tables 2 and 3 ).

In order to evaluate the relationship between the above mentioned variables, Pearson's coefficient of Bivariate correlation was calculated, test of significance was two tailed method (Table 4).

\section{RESEARCH RESULTS}

The indices of judokas' hand-grip strength $(\mathrm{kg})$ and the lung vital capacity (Liters) by age and weight categories are provided in the Tables 2 and 3.

The obtained data are reported in Figures 1 and 2 , reflecting the mean values of hand-grip strength and the lung vital capacity considering the age and weight categories.

In order to determine the possible correlation between the received data, as it was mentioned in "Statistics", Pearson's coefficient of Bivariate correlation was used. The data displayed in Table 4, indicate the reliable correlative affect on each other of the weight category, hand-grip strength and lung vital capacity increases.

\section{DISCUSSION}

The data obtained show that the average indices of strength of hand-grip and lung vital capacity increase with age and weight category of judokas (see Figures 1 and 2). Even in case of the same weight category, the greater the age of a judoka is, the higher the results are, though the results do not increase equally that would give the possibility to determine the stage of motor development.

In L. W. Wołkow's (1998) study concerning the aforementioned motor development stage three levels of children and young people's particular growth of physical capacities are identified: 8 - to 9 years, 10 - to 12 years and 13 - to 14 years of age.

According to the results obtained by W. Jagiełlo et al. (2007), the most effective period for motor development of young male judokas is $14-15$ years of age. Instead, in our data we observed one especially distinguished level of motor development. Its range is relatively wide, and it covers $13-15$ years of age, which should be conditioned by the tested persons' involvement in sports, particularly in judo and as a result of prolonged phase of motor development, which is clearly seen in Figures 1 and 2. The same figures show that hand-grip strength and lung vital capacity increase almost equally with age and weight category. Besides visual effects noticed in figures, the reliability of this fact is also proved by the data in Table 4, where the correlation accuracy between them is over $95 \%$.

\section{CONCLUSIONS AND PERSPECTIVES}

Even at the level of the age and weight categories there is a close relation between motor system and respiratory muscles, and it is desirable to take this fact into account in planning the learning-training process in order to facilitate the creation of equal 


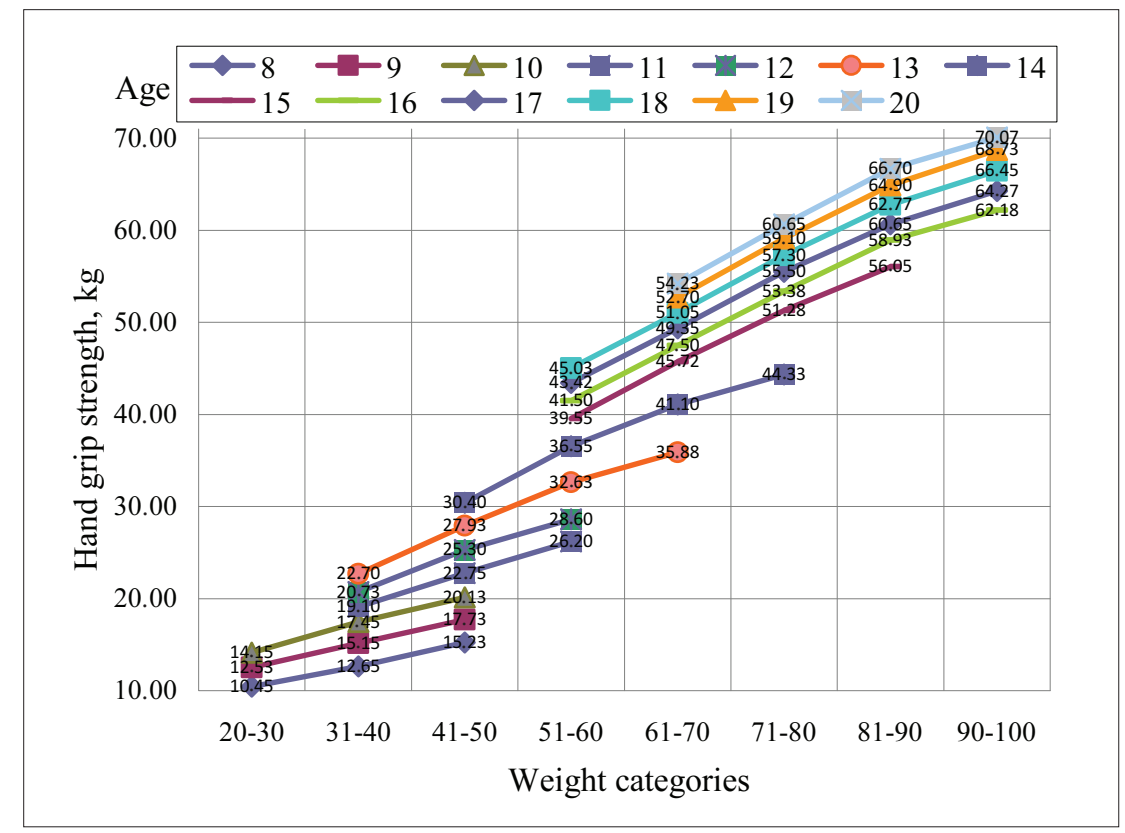

Figure 1. The mean value of hand grip strength in different age and weight categories of judokas

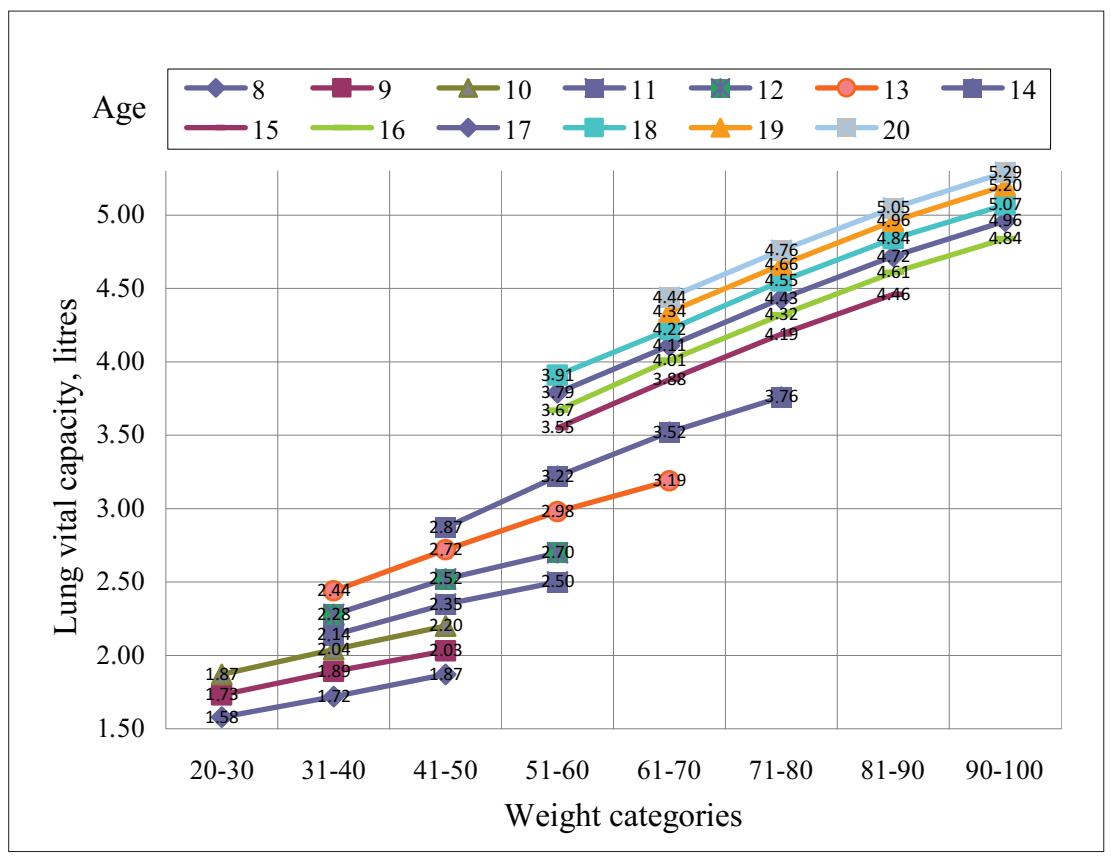

Figure 2. The mean value of lung vital capacity in different age and weight categories of judokas

preconditions for the physical and functional development of the body.

The research results will find their application in practical activities, if we compare the individual judokas' results with those obtained by us.

It has become possible to determine the rate of future physical and functional development for judokas of different age and weight categories in advance, being an important precondition for the regulation of learning-training process.

Based on the results of the research, promising judokas, training in different regions of Georgia were revealed, their data were passed over to the leading coaches, and they were recommended for individual training because of their high athletic abilities.

Further research should continue to identify the mean, maximum and minimum growth rates of cognitive processes as well. It would probably make it even easier to manage judoka's training which involves the development of physical, functional and cognitive abilities at each period of age.

Acknowledgements. In the process of research technical support was given by the Georgian Judo Federation. 
Table 2. Descriptive data of hand grip considering age and weight categories of judokas

\begin{tabular}{|c|c|c|c|c|c|c|c|c|c|c|c|c|c|c|c|}
\hline \multirow{4}{*}{ Age } & \multirow{4}{*}{$\mathbf{N}$} & \multicolumn{2}{|c|}{$\begin{array}{l}\text { Weight of } \\
\text { judokas, kg }\end{array}$} & \multicolumn{8}{|c|}{ Weight categories (kg)/minimum and maximum for 'weight of judokas' } & & & & \\
\hline & & \multirow{3}{*}{$\sum_{\Sigma}^{\bar{\Xi}}$} & \multirow{3}{*}{ 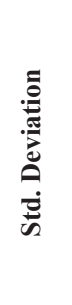 } & 周 & $\frac{P}{9}$ & $\frac{8}{7}$ & $\frac{8}{\frac{1}{n}}$ & $\frac{R}{\frac{1}{6}}$ & $\frac{\infty}{1}$ & $\frac{i}{\infty}$ & $\frac{8}{\frac{1}{a}}$ & & & & \\
\hline & & & & \multicolumn{12}{|c|}{ Hand grip strength, $\mathrm{kg}$} \\
\hline & & & & \multicolumn{8}{|c|}{ Mean } & 悹 & 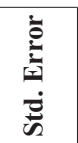 & 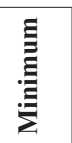 & 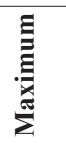 \\
\hline 8 & 40 & 25.35 & 2.547 & 10.45 & & & & & & & & 2.572 & 0.407 & 6 & 15 \\
\hline 8 & 40 & 34.28 & 2.075 & & 12.65 & & & & & & & 3.034 & 0.48 & 7 & 18 \\
\hline 8 & 40 & 44.3 & 2.115 & & & 15.23 & & & & & & 3.69 & 0.583 & 8 & 22 \\
\hline 9 & 40 & 25.18 & 3.054 & 12.53 & & & & & & & & 2.611 & 0.413 & 8 & 17 \\
\hline 9 & 40 & 34.18 & 2.183 & & 15.15 & & & & & & & 2.905 & 0.459 & 9 & 20 \\
\hline 9 & 40 & 44.88 & 2.388 & & & 17.73 & & & & & & 4.006 & 0.633 & 10 & 25 \\
\hline 10 & 40 & 24.65 & 3.06 & 14.15 & & & & & & & & 2.914 & 0.461 & 9 & 19 \\
\hline 10 & 40 & 34.67 & 2.712 & & 17.45 & & & & & & & 3.396 & 0.537 & 11 & 23 \\
\hline 10 & 40 & 45.6 & 2.845 & & & 20.13 & & & & & & 4.127 & 0.653 & 13 & 28 \\
\hline 11 & 40 & 35.45 & 2.81 & & 19.1 & & & & & & & 3.35 & 0.53 & 13 & 25 \\
\hline 11 & 40 & 45.4 & 2.96 & & & 22.75 & & & & & & 5.237 & 0.828 & 15 & 31 \\
\hline 11 & 40 & 54.58 & 2.581 & & & & 26.2 & & & & & 5.205 & 0.823 & 18 & 34 \\
\hline 12 & 40 & 36.08 & 2.759 & & 20.73 & & & & & & & 3.457 & 0.547 & 14 & 27 \\
\hline 12 & 40 & 44.2 & 2.377 & & & 25.3 & & & & & & 5.175 & 0.818 & 17 & 33 \\
\hline 12 & 40 & 55.15 & 2.527 & & & & 28.6 & & & & & 5.606 & 0.886 & 20 & 37 \\
\hline 13 & 40 & 34.33 & 2.536 & & 22.7 & & & & & & & 3.299 & 0.522 & 16 & 29 \\
\hline 13 & 40 & 46.32 & 2.712 & & & 27.93 & & & & & & 4.526 & 0.716 & 20 & 36 \\
\hline 13 & 40 & 54 & 2.449 & & & 21.75 & 32.63 & & & & & 5.873 & 0.929 & 23 & 41 \\
\hline 13 & 40 & 66.28 & 2.65 & & & & & 35.88 & & & & 5.501 & 0.87 & 26 & 47 \\
\hline 14 & 40 & 45.38 & 2.844 & & & 30.4 & & & & & & 5.372 & 0.849 & 22 & 38 \\
\hline 14 & 40 & 56.38 & 2.192 & & & & 36.55 & & & & & 5.657 & 0.894 & 27 & 45 \\
\hline 14 & 40 & 64.25 & 2.307 & & & & & 41.1 & & & & 5.606 & 0.886 & 31 & 52 \\
\hline 14 & 40 & 76.07 & 2.358 & & & & & & 44.33 & & & 7.109 & 1.124 & 32 & 57 \\
\hline 15 & 40 & 56.15 & 3.167 & & & & 39.55 & & & & & 6.243 & 0.987 & 29 & 49 \\
\hline 15 & 40 & 65.4 & 2.509 & & & & & 45.72 & & & & 5.853 & 0.925 & 35 & 56 \\
\hline 15 & 40 & 74.25 & 2.436 & & & & & & 51.28 & & & 8.003 & 1.265 & 39 & 63 \\
\hline 15 & 40 & 85.45 & 2.736 & & & & & & & 56.05 & & 7.916 & 1.252 & 43 & 69 \\
\hline 16 & 40 & 54.27 & 2.522 & & & & 41.5 & & & & & 6.106 & 0.965 & 31 & 51 \\
\hline 16 & 40 & 66.6 & 2.725 & & & & & 47.5 & & & & 4.466 & 0.706 & 37 & 58 \\
\hline 16 & 40 & 75.15 & 2.597 & & & & & & 53.38 & & & 6.927 & 1.095 & 42 & 66 \\
\hline 16 & 40 & 86.02 & 2.796 & & & & & & & 58.93 & & 7.627 & 1.206 & 46 & 72 \\
\hline 16 & 40 & 95.05 & 2.736 & & & & & & & & 62.18 & 8.048 & 1.272 & 50 & 76 \\
\hline 17 & 40 & 55.75 & 2.447 & & & & 43.42 & & & & & 5.813 & 0.919 & 34 & 53 \\
\hline 17 & 40 & 67.62 & 2.261 & & & & & 49.35 & & & & 4.594 & 0.726 & 39 & 60 \\
\hline 17 & 40 & 75.95 & 2.791 & & & & & & 55.5 & & & 7.042 & 1.113 & 44 & 69 \\
\hline 17 & 40 & 85.68 & 2.777 & & & & & & & 60.65 & & 8.502 & 1.344 & 48 & 74 \\
\hline 17 & 40 & 95.65 & 2.527 & & & & & & & & 64.27 & 8.286 & 1.31 & 52 & 78 \\
\hline 18 & 40 & 56.33 & 2.117 & & & & 45.03 & & & & & 5.673 & 0.897 & 36 & 54 \\
\hline 18 & 40 & 66.58 & 2.659 & & & & & 51.05 & & & & 5.233 & 0.827 & 41 & 62 \\
\hline 18 & 40 & 75.62 & 2.761 & & & & & & 57.3 & & & 8.156 & 1.29 & 46 & 71 \\
\hline 18 & 40 & 85.88 & 2.503 & & & & & & & 62.77 & & 8.094 & 1.28 & 51 & 77 \\
\hline 18 & 40 & 95.57 & 2.438 & & & & & & & & 66.45 & 7.449 & 1.178 & 54 & 80 \\
\hline 19 & 40 & 66.43 & 2.716 & & & & & 52.7 & & & & 5.18 & 0.819 & 42 & 64 \\
\hline 19 & 40 & 75.3 & 2.633 & & & & & & 59.1 & & & 7.725 & 1.221 & 47 & 73 \\
\hline 19 & 40 & 85.1 & 2.458 & & & & & & & 64.9 & & 8.351 & 1.32 & 53 & 79 \\
\hline 19 & 40 & 96.37 & 2.404 & & & & & & & & 68.73 & 7.261 & 1.148 & 56 & 82 \\
\hline 20 & 40 & 66.95 & 2.32 & & & & & 54.23 & & & & 5.299 & 0.838 & 43 & 65 \\
\hline 20 & 40 & 75.58 & 2.48 & & & & & & 60.65 & & & 7.181 & 1.135 & 48 & 74 \\
\hline 20 & 40 & 86.55 & 2.396 & & & & & & & 66.7 & & 7.819 & 1.236 & 54 & 80 \\
\hline 20 & 40 & 95.43 & 2.395 & & & & & & & & 70.07 & 6.746 & 1.067 & 58 & 84 \\
\hline
\end{tabular}


Table 3. Descriptive data of lung vital capacity considering age and weight categories of judokas

\begin{tabular}{|c|c|c|c|c|c|c|c|c|c|c|c|c|c|c|c|}
\hline \multirow{4}{*}{ Age } & \multirow{4}{*}{$\mathbf{N}$} & \multicolumn{2}{|c|}{$\begin{array}{c}\text { Weight of } \\
\text { judokas, kg }\end{array}$} & \multicolumn{8}{|c|}{ Weight categories (kg) / minimum and maximum for 'weight of judokas' } & & & & \\
\hline & & \multirow{3}{*}{$\sum_{\Sigma}^{\bar{\Xi}}$} & \multirow{3}{*}{ 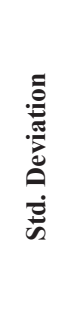 } & 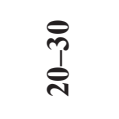 & $\frac{P}{\dot{f}}$ & $\frac{i}{7}$ & $\frac{8}{1}$ & $\frac{1}{\frac{1}{6}}$ & $\begin{array}{l}\infty \\
\frac{1}{1}\end{array}$ & $\frac{a}{\infty}$ & $\frac{8}{\frac{1}{a}}$ & & & & \\
\hline & & & & \multicolumn{12}{|c|}{ Lung vital capacity, litres } \\
\hline & & & & \multicolumn{8}{|c|}{ Mean } & 密 & 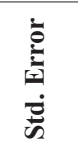 & 声 & 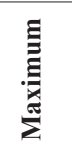 \\
\hline 8 & 40 & 25.35 & 2.547 & 1.58 & & & & & & & & 0.219 & 0.035 & 1.1 & 2 \\
\hline 8 & 40 & 34.28 & 2.075 & & 1.72 & & & & & & & 0.223 & 0.035 & 1.2 & 2.1 \\
\hline 8 & 40 & 44.3 & 2.115 & & & 1.87 & & & & & & 0.221 & 0.035 & 1.4 & 2.3 \\
\hline 9 & 40 & 25.18 & 3.054 & 1.73 & & & & & & & & 0.205 & 0.032 & 1.3 & 2.1 \\
\hline 9 & 40 & 34.18 & 2.183 & & 1.89 & & & & & & & 0.253 & 0.04 & 1.4 & 2.3 \\
\hline 9 & 40 & 44.88 & 2.388 & & & 2.03 & & & & & & 0.236 & 0.037 & 1.6 & 2.5 \\
\hline 10 & 40 & 24.65 & 3.06 & 1.87 & & & & & & & & 0.263 & 0.042 & 1.5 & 2.3 \\
\hline 10 & 40 & 34.67 & 2.712 & & 2.04 & & & & & & & 0.31 & 0.049 & 1.5 & 2.5 \\
\hline 10 & 40 & 45.6 & 2.845 & & & 2.2 & & & & & & 0.283 & 0.045 & 1.7 & 2.7 \\
\hline 11 & 40 & 35.45 & 2.81 & & 2.14 & & & & & & & 0.295 & 0.047 & 1.7 & 2.6 \\
\hline 11 & 40 & 45.4 & 2.96 & & & 2.35 & & & & & & 0.326 & 0.052 & 1.8 & 2.9 \\
\hline 11 & 40 & 54.58 & 2.581 & & & & 2.5 & & & & & 0.358 & 0.057 & 1.9 & 3.1 \\
\hline 12 & 40 & 36.08 & 2.759 & & 2.28 & & & & & & & 0.304 & 0.048 & 1.8 & 2.8 \\
\hline 12 & 40 & 44.2 & 2.377 & & & 2.52 & & & & & & 0.31 & 0.049 & 1.9 & 3 \\
\hline 12 & 40 & 55.15 & 2.527 & & & & 2.7 & & & & & 0.317 & 0.05 & 2.1 & 3.3 \\
\hline 13 & 40 & 34.33 & 2.536 & & 2.44 & & & & & & & 0.299 & 0.047 & 1.9 & 2.9 \\
\hline 13 & 40 & 46.32 & 2.712 & & & 2.72 & & & & & & 0.347 & 0.055 & 2.1 & 3.3 \\
\hline 13 & 40 & 54 & 2.449 & & & & 2.98 & & & & & 0.321 & 0.051 & 2.3 & 3.6 \\
\hline 13 & 40 & 66.28 & 2.65 & & & & & 3.19 & & & & 0.421 & 0.067 & 2.5 & 3.9 \\
\hline 14 & 40 & 45.38 & 2.844 & & & 2.87 & & & & & & 0.352 & 0.056 & 2.2 & 3.5 \\
\hline 14 & 40 & 56.38 & 2.192 & & & & 3.22 & & & & & 0.321 & 0.051 & 2.6 & 3.9 \\
\hline 14 & 40 & 64.25 & 2.307 & & & & & 3.52 & & & & 0.543 & 0.086 & 2.7 & 4.4 \\
\hline 14 & 40 & 76.07 & 2.358 & & & & & & 3.76 & & & 0.59 & 0.093 & 2.8 & 4.8 \\
\hline 15 & 40 & 56.15 & 3.167 & & & & 3.55 & & & & & 0.416 & 0.066 & 2.8 & 4.3 \\
\hline 15 & 40 & 65.4 & 2.509 & & & & & 3.88 & & & & 0.564 & 0.089 & 2.9 & 4.7 \\
\hline 15 & 40 & 74.25 & 2.436 & & & & & & 4.19 & & & 0.574 & 0.091 & 3.2 & 5.2 \\
\hline 15 & 40 & 85.45 & 2.736 & & & & & & & 4.46 & & 0.596 & 0.094 & 3.4 & 5.5 \\
\hline 16 & 40 & 54.27 & 2.522 & & & & 3.67 & & & & & 0.529 & 0.084 & 2.9 & 4.5 \\
\hline 16 & 40 & 66.6 & 2.725 & & & & & 4.01 & & & & 0.503 & 0.08 & 3 & 4.9 \\
\hline 16 & 40 & 75.15 & 2.597 & & & & & & 4.32 & & & 0.578 & 0.091 & 3.3 & 5.3 \\
\hline 16 & 40 & 86.02 & 2.796 & & & & & & & 4.61 & & 0.621 & 0.098 & 3.5 & 5.6 \\
\hline 16 & 40 & 95.05 & 2.736 & & & & & & & & 4.84 & 0.777 & 0.123 & 3.7 & 6.1 \\
\hline 17 & 40 & 55.75 & 2.447 & & & & 3.79 & & & & & 0.504 & 0.08 & 3 & 4.6 \\
\hline 17 & 40 & 67.62 & 2.261 & & & & & 4.11 & & & & 0.462 & 0.073 & 3.1 & 5.1 \\
\hline 17 & 40 & 75.95 & 2.791 & & & & & & 4.43 & & & 0.548 & 0.087 & 3.4 & 5.4 \\
\hline 17 & 40 & 85.68 & 2.777 & & & & & & & 4.72 & & 0.614 & 0.097 & 3.6 & 5.8 \\
\hline 17 & 40 & 95.65 & 2.527 & & & & & & & & 4.96 & 0.75 & 0.119 & 3.8 & 6.2 \\
\hline 18 & 40 & 56.33 & 2.117 & & & & 3.91 & & & & & 0.457 & 0.072 & 3.1 & 4.7 \\
\hline 18 & 40 & 66.58 & 2.659 & & & & & 4.22 & & & & 0.453 & 0.072 & 3.2 & 5.2 \\
\hline 18 & 40 & 75.62 & 2.761 & & & & & & 4.55 & & & 0.612 & 0.097 & 3.5 & 5.6 \\
\hline 18 & 40 & 85.88 & 2.503 & & & & & & & 4.84 & & 0.632 & 0.1 & 3.7 & 6 \\
\hline 18 & 40 & 95.57 & 2.438 & & & & & & & & 5.07 & 0.724 & 0.114 & 3.9 & 6.3 \\
\hline 19 & 40 & 66.43 & 2.716 & & & & & 4.34 & & & & 0.375 & 0.059 & 3.3 & 5.3 \\
\hline 19 & 40 & 75.3 & 2.633 & & & & & & 4.66 & & & 0.585 & 0.093 & 3.6 & 5.7 \\
\hline 19 & 40 & 85.1 & 2.458 & & & & & & & 4.96 & & 0.8 & 0.126 & 3.8 & 6.2 \\
\hline 19 & 40 & 96.37 & 2.404 & & & & & & & & 5.2 & 0.671 & 0.106 & 4 & 6.4 \\
\hline 20 & 40 & 66.95 & 2.32 & & & & & 4.44 & & & & 0.392 & 0.062 & 3.4 & 5.4 \\
\hline 20 & 40 & 75.58 & 2.48 & & & & & & 4.76 & & & 0.552 & 0.087 & 3.7 & 5.8 \\
\hline 20 & 40 & 86.55 & 2.396 & & & & & & & 5.05 & & 0.648 & 0.102 & 3.9 & 6.3 \\
\hline 20 & 40 & 95.43 & 2.395 & & & & & & & & 5.29 & 0.644 & 0.102 & 4.1 & 6.5 \\
\hline
\end{tabular}




\begin{tabular}{|c|c|c|c|c|c|}
\hline \multirow[t]{7}{*}{$\begin{array}{l}\text { Table 4. Correlations of weight, hand } \\
\text { grip strength and lung vital capacity }\end{array}$} & & & $\begin{array}{c}\text { Weight } \\
\text { category }\end{array}$ & Hand grip & $\begin{array}{l}\text { Lung vital } \\
\text { capacity }\end{array}$ \\
\hline & \multirow{3}{*}{$\begin{array}{l}\text { Weight } \\
\text { category }\end{array}$} & Pearson Correlation & 1 & $0.934(* *)$ & $0.902(* *)$ \\
\hline & & Sig. (2-tailed) & & 0.000 & 0.000 \\
\hline & & $\mathrm{N}$ & 2000 & 2000 & 2000 \\
\hline & \multirow{3}{*}{ Hand grip } & Pearson Correlation & $0.934(* *)$ & 1 & $0.976(* *)$ \\
\hline & & Sig. (2-tailed) & 0.000 & & 0.000 \\
\hline & & $\mathrm{N}$ & 2000 & 2000 & 2000 \\
\hline \multirow{3}{*}{$\begin{array}{l}\text { Note. } * * \text { - correlation is significant at the } \\
0.01 \text { level (2-tailed). }\end{array}$} & \multirow{3}{*}{$\begin{array}{l}\text { Lung vital } \\
\text { capacity }\end{array}$} & Pearson Correlation & $0.902(* *)$ & $0.976(* *)$ & 1 \\
\hline & & Sig. (2-tailed) & 0.000 & 0.000 & \\
\hline & & $\mathrm{N}$ & 2000 & 2000 & 2000 \\
\hline
\end{tabular}

\title{
REFERENCES
}

Banovic, I. (2001). Possible judo performance prediction based on certain motor abilities and technical knowledge (skills) assessment. Kinesiology (Zagreb), 33 (2), 191206.

Chitashvili, D. (2005). Kardio-respiratoruli da kuntovani sistemebis funqcionireba fizikuri datvirtvebis dros. Tbilisi: Mecniereba.

Chitashvili, D., Zubitashvili, G., Korinteli, E. (2010). Bavshvta sportuli proforientaciis kriteriumebi. Saqartvelos mecnierebata erovnuli akademiis macne (biomedicinis seria), 36 (5-6), 373-380.

Dopsaj, M., Koropanovski, N., Vubkovic, G. et al. (2007). Maximal isometric hand grip force in welltrained university students in Serbia: Descriptive, functional and sexual dimorphic model. Serbian Journal of Sports Sciences, 1 (4), 138-147.

Franchini, E., Takito, M. Y., Kiss, M. et al. (2005). Physical fitness and anthropometrical differences between elite and non-elite judo players. Biology of Sport, 22 (4), 315-328.

Jagiełlo, W., Kalina, R. M. (2007). Properties of motor development in young judokas. Journal of Human Kinetics, 17, 113-120.

Leyk, D., Gorges, W., Ridder, D. et al. (2007). Hand-grip strength of young men, women and highly trained female athletes. European Journal of Applied Physiology, 99 (4), 415-421.

Marchocka, M. (1992). La costituzione fisica e strutturale del judoka. Athlon (Roma), 3, 41-45.

Pedro, J. (2001). Judo Techniques \& Tactics. United States: Human Kinetics.

Wołkow, L. W. (1998). Sportiwnaja podgotowka dietiej i podrostkow. Kijów: Wieża.

Zubitashvili, G. (2010). Sacvrtno procesis regulireba. Saqartvelos ganatlebis mecnierebata akademiis moambe, 11, 167-172.

\section{DZIUDO TRENIRUOTĖS VYKSMO REGULIAVIMAS PAGAL FIZINIUS IR FUNKCINIUS RODIKLIUS}

\author{
Giorgi Zubitashvili \\ Ilia valstybinis universitetas, Tbilisis, Gruzija
}

\section{SANTRAUKA}

Tyrimo pagrindimas ir hipoteze. Dziudo technikos specifika reikalauja, kad būtų atliekami labai meistriški, greiti ir galingi judesiai, todèl labai svarbu ugdyti sportininkų aerobinį pajėgumą bei judamają sistemą, ypač plaštakų jègą.

Tikslas: ištirti dziudo imtynininkų plaštakų jẻgą, plaučių gyvybini pajėgumą amžiaus bei svorio kategorijų požiūriu ir nustatyti tinkamiausią amžiu šioms savybėms ugdyti.

Metodai. Tyrimai buvo atliekami per pratybas 2009-2011 m. ciklo metu. Tirta 2000 vyru - 8-iu svorio kategoriju dziudo imtynininkų. Matavimai buvo atliekami dinamometru ir spirometru. Gauti rezultatai apdoroti SPSS 19 statistine programa taikant dispersinès analizès metoda. 
Rezultatai. Vidutiniai plaštaku jègos ir plaučiu gyvybinio pajègumo rodikliai su amžiumi ir kintant svorio kategorijai didèjo, tačiau nereguliariai. Geriausias judamojo aparato augimo laikotarpis yra 13-15 metu amžius tada pasiekiama geriausių sportinių rezultatų. Aptiktas koreliacinis ryšys tarp plaštaku jègos ir plaučiu gyvybinio pajëgumo rodikliu.

Aptarimas ir išvados. Tarp sportininko judamosios sistemos ir raumenų, dalyvaujančiu kvėpavimo procese, yra glaudus ryšys.

Raktažodžiai: plaštakos jèga, plaučiu gyvybinis tūris, duomenų kaitumas, praktinė vetrè.

Gauta 2011 m. liepos $21 \mathrm{~d}$.

Received on July 21, 2011

Priimta $2011 \mathrm{~m}$. rugsèjo $9 \mathrm{~d}$.

Corresponding author Giorgi Zubitashvili

Accepted on September 9, 201

Ilia State University

Kakutca Cholokashvili Ave., 3/5, Tbilisi 0162

Georgia

Tel 599479075

E-mailg.zubitashvili@iliauni.edu.ge 